\title{
Countering Anthropocentric Perspective of Ecology with the Dictum of the Gita
}

\author{
--Bam Dev Adhikari \\ Associate Professor of English, \\ Tri-Chandra Campus, Tribhuvan University, \\ Kathmandu, Nepal. \\ Email: adhikaribamdev@gmail.com
}

https://doi.org/10.3126/litstud.v34i01.39519

\begin{abstract}
Human beings and the natural world have remained in constant collision with each other since the beginning of human civilization. The biosphere is shared by millions living beings including human beings.

From the early days of human civilization, human beings kept themselves in the centre and developed an attitude of us and them, human beings us and the entire plants, animals and elements them. In Complete anthropocentric perspective of development of about ten thousand years, human beings never thought about the impacts upon the natural world and as a result the entire earth is in disfigured appearance now. In this essay, I have made an argument that only karma irrespective of the benefits can slow down or even reverse the conflict between human beings and the natural world.
\end{abstract}

Keywords: Ecology, Natural World, Anthropocentrism, Conflict, Confrontation, Center, Decentering

We are now confronting the era of total ecocide unprecedented in our civilization's history; life sustaining faculty of the earth has come in critical juncture and we begin to be haunted by apocalyptic trepidation. In the name of development and advancement, we have disfigured the face of the earth beyond recognition. Borrowing Murphy's words, ours is the era when natural world has been completely mediated and appropriated either by intervention or by manipulation or by transformation of natural resources (194). Every alteration in nature has been made from man's prospective, by putting man in the central position. In the course of fulfilling our insatiable demands, we have exploited the entire plants, animals and elements (PAEs) irrevocably. We now have realization of our 
mistakes and we are trying to roll back our deeds but in vain. All our anthropocentric attempts have failed to do justice to ecology and, it seems there is no alternative left except waiting for our apocalypse. In this critical moment, only karma, the dictum of The Bhagwad Gita can guarantee the survival of ecology and mankind in the truest sense.

The Bhagvad Gita, is the most cherished and popular book of wisdom and spiritual insight in Hinduism. In the battle field of Kurukchhetra in the epic Mahabharata, Lord Krishna preaches bewildered Arjuna:

KarmanyaVadhikaresteMaaphalesuKadachana

Karma PhalehetubhurbatesangostavKarmani.

English translation:

To action alone has thou right not to its fruit

Let not fruit be thy motive, nor must thou be inactive.

The couplet is the most quoted portion of the Gita. Most of the literate Hindu people know the couplet by heart but they rarely think about its underlying meaning. The Bhagvad Gita's this dictum expects people to give up desire or interest for the fruit of their action. Is it possible? Are there such selfless people in the world?

Empirical evidence shows that human action always entails individual or communal benefit. Environmental/ecological protection can rarely be an exception. Contrary to the desire for fruit of our action, the Gita, suggests the path of complete annihilation or surrender of our desire for fruit. If the same dictum of the Gita is applied in other spheres of human endeavor, then why is it not applied in case of ecology? If we assimilate this dictum of the Gita, it will inspire us to seek ways of overcoming environmental crisis irrespective of our pleasure and wellbeing. The ecological crisis is the product of anthropocentric perspective and ecology cannot survive in the long run unless this perception is reversed.

Nobody has defined anthropocentricism as has Alan Liu. Liu argues, "Nature is the name under which we use the non human to validate the human, to interpose mediation able to make humanity more easy with itself" (Qtd in Bate 171). Liu establishes a perspective for the rationalization of man's injustice done to the natural world. This rationalization takes all natural resources as gifts of nature given to man free of cost and he has every right to use them in any way he likes. However, this anthropocentric view is being questioned in recent years. Countering Alan Liu, Bate writes, "Human civilization has always been in 
the business of altering the land whether through deforestation or urbanization or mining or enclosure or artificial re-imposition of nature . . ."(171).This "altering of the land" is the process that brought ecological crisis to this intensity. Similarly Val Plumwood assumes anthropocentrism the same as human instrumentalism. She argues:

The initial rejecting of instrumentalism provides a gateway for environmental ethics, opening the way for construction of a more substantial ethic by admitting the nonhumans to the universe of ethical discourse from which they were excluded by dualistic ethical framework of which consigned nature to a special lower category of expediency. (125)

By the words "dualistic ethical framework", Plumwood signals us/them dichotomy, human beings as us and natural world (PAE) as them, anexplicit hierarchy between human being and natural world. Hence, the scholars are found in two opposite poles: the former justifying man's actions or man's activities on nature and the latter defending the right of the natural world, the right of the entire PAEs. The second group of scholars believes that the planet's life support system has come under question whether the natural world can sustain life in meaningful way or not. That's why, this group has waged war for the survival of the planet.

To undertake the ecological battle, once we ignored better and more painless path of prevention and we are now trying to find more expensive path of cure. The scholars are suggesting numerous ways of alternatives to avert the day of apocalypse by saving earth's life support system. According to Moti Nissani, ecology can be saved by controlling our numbers and our appetites (35). For Anuradha Chaudhary," The health of the biosphere depends on humanity's ability to change its way of thinking and doing politics ...."(182) . Likewise, Patrick D. Murphy is in favor of a triad of ecology, feminism and Bakthinian dialogic method to fight against totalization done on both ecology and women (193).Cheryl Glotfelty wants to take the help of theology and rituals. According to him "Some theologians turn to ancient Earth Goddess worship, Eastern religious tradition and Native American teachings, belief systems that contain much wisdom about nature and spirituality "(xxii). These aforementioned ways, though positive, are insufficient at this critical juncture. Ecology cannot be protected, as Nissani and others suggest, without our sincere praxis in changing our way of thinking and in 
controlling our appetites. Hence the dictum of the Gita seems to match the urgency of time for the longevity of the natural world, PAEs.

The dictum of the Gita can save the ecology from deteriorating further leading the natural world towards catastrophe by enhancing our ethical self. The natural world suffers because of its monetary assessment, for the capitalistic worldview has shaped our mind which tries to see every natural resource in terms of price. Modern man, in his race for profit and gain in this pre-collapse world, has forgotten his ethics, and, as a result, the natural world has succumbed to his exploitation. In the present predicament, the ecological discrepancy can be corrected by correcting man's action, by reminding him the ethics of his Karma. The dictum of the Gita reminds us the importance of Tyag.

Renunciation or Tyag should consist of right action done without any desire for fruit or profit. Here, renunciation is not of the world, not of the karma but of desire for fruit. Basically two motives are seen behind any action: selfish motive and selfless motive. The one stems from the desire of some benefit and the other from altruistic principle. The first makes his action a ladder or anchor for his post or position but the other renders disinterested service for the sake of altruism. Such cases are found in identity politics where people, working on behalf of some subaltern groups, expect to go up as their leaders. Still, there were and even are people who serve for the sake of service without any desire of going up. The instances of selfless Karma can be found in social service. For example, Mother Teresa, Florence Nightingale and even Mahatma Gandhi were disinterested social workers who sacrificed their lives for the wellbeing of poor and needy people. If a person serves poor and downtrodden people without any desire for profit, the same motive of social service can certainly be applied in the case of ecology too. A person can become a true altruistic ecologist by following the dictum of the Gita, KarmanyaVadhikareste.

The examples of profitless Karma are found even in Buddhist mythology. An anecdote from Buddhist mythology favors renunciation or Tygafor altruistic reason. The story runs:

Once, Buddha was born as a parrot. One day the forest caught fire and many animals were trapped in the forest fire. As the parrot was flying towards a safe location, his heart kindled with pity towards trapped animals. He flew to the river, dipped in water and came back to the burning forest with a few drops of water. At that time the carefree gods laughed at the bird and criticized him saying 
"Look at the foolish bird; he is trying to put out the forest fire by a few drops of water". The bird was not discouraged by them and continued with his work. Later, one of the gods was impressed by the bird's actions and helped him to put out the forest fire.

The bird in the story seems altruistic towards the trapped animals. He knew that he was doing futile attempts; a few drops of water could not put out the forest fire, but he was doing his disinterested Karma sincerely. The bird was not destined to bring more water than a few drops. He understood it well that he could not bring more water than his container contained. The story inspires the workers of ecology too. We cannot save the vast ecology by our single attempt. The prospective of Karma suggests that we should not try to put the whole burden on our shoulder. Our individual action may be like a few drops of water in a burning forest but it can set a model of Karma. Like the bird in the story, Gautam Buddha was also not discouraged from carrying out his Karma. R. K Tondon relates Buddha's action with the Karma of the Gita and says, "Gautam Buddha preached the same gospel of work relentless struggle carried out with joy and enthusiasm" (68). Buddha continued preaching without any desire for fruit. Likewise, an environmental worker should work in the spirit of Buddha assimilating the dictum KarmanyaVadhikaresta .... .

Val Plumwood talks about one Buddhist story in one of her articles. She writes:

In a previous incarnation as a prince, the Buddha is said to have sacrificed himself to save a starving tiger and her cubs. As the story goes, "Prince Mahasaavta slits his throat with a piece of wood and allows the tigress to drink his blood and devour him completely. (131)

The story exemplifies the sacrifice of man for the sake of animals. According to Plumwood, this narrative reflects Buddhism's philosophical underpinning- a metaphysics that insists on unitary nature of all beings, a personhood that treats continuity with nonhuman animals (131). Buddhist mythology may not be expecting the same kind of sacrifice from human beings but it has set a viewpoint that if need be we have to be ready for the sacrifice of our own self or ego. This mythical example may not be a model in human action, however we can find a lot of examples o in human vicinity, where people do selfless Karma not for fruit but for happiness.

Here happiness should not be taken synonymous to fruit or interest, for, the word happiness is impartial word; even the sages get 
happiness in their meditative trance. Like the Gita, Benjamin Disraeli writes, "Action may not always bring you happiness but you cannot be happy without action" (qtd in Arnold 69). We now hear the stories of tree huggers saying "saw me before you saw this tree". The tree huggers do not get anything except sheer happiness of seeing the tree in its intrinsic value. Expressing his hostility towards ecocide Edward Abbey suggests common people that they should spike the tree with 60 penny nails so as to save them from tree loggers. If done so, human beings would not hurt the tree; instead the tree would be grateful to them (346-7). Ecology suffers from wrong actions of bad people; it even suffers more from inaction of good people. So the dictum of the Gita does not want people to languish in inaction, nor must thou be inactive.

On the other hand, man's actions on behalf of ecology are being questioned by his fellow men. People have raised questions saying human beings cannot work as ventriloquists, as plaintiffs of the natural world. To respond such people, an ecocriticJhan Hochman makes an analogy from modern legal system, where a lawyer, a human being represents another human being. If a man, a conscious being can be represented by another man, why can't the natural world be represented by a man (187-92)? Natural world is not damned to suffer without any rescuer. Of course, we can work as a plaintiff of ecology but, at the same time, we should be conscious of another facet of the coin as well. The ecological workers should be careful of the cunning people, who can turn ecology into dollar digging shovel in the guise of ventriloquism. If profit motive comes ahead of altruism, the dictum of the Gita fails and ecology suffers. The world does not lack such profit seeking ventriloquists.

BBC Nepali service in the news bulletin of January 4, 2011 made a report of forest conservation in Kailali, a far western district of Nepal. The report said that some areas of forest were being occupied and conserved by academic institutions like schools and colleges in order to sell the resources in the time of financial crisis. This situation is ironic, as in this context, forest conservation cannot be differentiated from poultry farming and fish ponds. Forest conservation cannot be made altruistic unless it is seen from the prospective of Karma.

Sincere Karma not only saves ecology from deteriorating but also brings salvation, freeing us from our sensory prison walls. In an American film "The Silence of the Lambs", a girl named Clarice tries to save a lamb from being killed in the slaughter house but she fails in her attempt. The girl suffers from mental stress: the shrill of the lamb echoes in her mind 
constantly. After some time she is able to free a woman from the custody of a policeman. She does not hear the shrill any longer after the moment she frees the woman. Clarice's actions while trying save the lamb or the woman are disinterested actions and this disinterested Karma frees her from her mental stress.

As discussed in connection with Val Plumwood earlier, anthropocentric world view has always seen the natural world as "things for us". The dichotomy of us/them has created a hierarchy between human being and the natural world, human being as the owners of the natural world and the PAEs as property of human beings. The dictum of the Gita helps us change our hierarchical paradigm into, as Patrick D Murphy suggests (194), heterarchical paradigm. Since the outlook of Karma does not see any fruit of action, there is no question of "things for us ". Instead of treating PAEs as things for us, our Karma helps us understand them as "things in themselves". In this context, the statement of Zen Philosopher seems relevant:

Before I studied Zen for 30 years, I saw mountains and waters as mountains and waters. When $I$ arrived at a more intimate knowledge, I came to the point where I saw that mountains are not mountains and waters are not waters. But now that I have its very substance I am at rest. For it's just that I see mountains once again as mountains and water once again as water. (qtd in Coupe 1)

The philosopher understood nature in three different phases of understandings. First he understood mountains and waters different from him, as others. In the second phase, the philosopher seems to have internalized things in his mind and heart. In the last phase, he understands mountains and waters as things in themselves in their own entity. The philosopher's third phase of understanding resembles with what Krishna said in the Gita. The essence of Karma is impartiality and disinterestedness towards things in general. The perspective of Karma sees the things in their own independent existence, in their own intrinsic value, not as the things of inherent human consumption by intervening, manipulating and transforming.

There are some bright rays far in the horizon showing that there are still some bright points in the abyss of anthropocentric and consumerist society. One disinterested person, a person guided by the sole spirit of Karma is Julia Butterfly Hill, an environmental activist who saved the redwood forest California. She is known as a tree sitter lady, who stayed in a redwood tree for 738 days to save the redwood trees being chopped 
down. Pacific Lumber Company was clearing the forest turning the area into a residential town. At a critical point when all the environmentalists were fighting a losing battle, Julia climbed on the tree on $10^{\text {th }}$ December 1997, stayed there for 738 days and climbed down it on $18^{\text {th }}$ December 1999 when an agreement was made to save the trees. She sacrificed more than two years not for any monetary benefit but for her Karma of saving redwood trees.

Another example, a warrior of karma is Lawrence Anthony, known as Elephant Whisperer, who worked with wild elephants in African nature reserve of ThulaThula. When Anthony passed away on $25^{\text {th }}$ July, 2012, a group of elephants came out of the reserved, walked to the African province of KwaZulu-Natal, stood around Anthony's house for two days and dispersed. Anthony had worked hard to save the wild elephants in the reserve from 1998. His love towards the elephants was completely disinterested, only a karma without expectation of monetary return. Had he turned his affairs with the elephants into a business, the elephants would not have come to his house to pay him a homage. The news of elephant paying homage to Anthony had become viral at that time.

A large number of examples of karma can be given from the Indian sub- continent where the scripture Gita is supposed to have been composed. India is a vast country, which has given births to many disinterested environmental workers. The name which leads the list of the impartial environmentalists is Sundar Lal Bahuguna, a Gandhian activist of Uttarakhand at the foot hills of the Himalayas. Bahuguna gave a proper direction and height to Chipiko movement, popularly known as ChipikoAndolan in India. It was a movement against the construction of Tehri Dam in the upper reaches of the Ganges River. Had the dam been constructed, the biodiversity of the Himalayan region would have been lost. Bahuguna's movement took the form of Satyagraha, in which thousands of people participated and finally became successful to stop the dam construction. It's because of hard work and sacrifice of SundarlalBahugunathat the ecology of the Himalayan region was not deteriorated. Hundreds of activists became active in India not for their personal benefit but for the impartial love of ecology. These names cannot be discussed here because of the limitation of space.

Although Nepal has not produced world renowned environmentalists, attempts have been made to make the people aware of the importance of ecology and environment. Madan Krishna Shrestha and 
Hari Bansha Acharya acted film Banpale (The Forest Guard) is a good example to create the awareness of forest and wildlife and to show the importance of karma. Set in Chitwan National Park, the film shows the confrontation between a forest guard and poachers and smugglers. The forest guard, Madan Krishna Shrestha could have earned millions of rupees if he had made agreements with the smugglers but he doesn't. He stands for the forest and the wild lives and suffers physical tortures and humiliations. These representative examples of disinterested and impartial warriors of karma have signaled that ecology and environment will have sustainability despite the incessant attacks made by consumerist anthropocentric perspectives.

The path of Karma is the path of ethics, and the world can only be saved when its main inhabitant man becomes friendly towards the entire plants animals and elements. The path of profit cannot correct man from doing injustice to the natural world and hence the path of Karmacan bring the reinvigorating breeze in sweltering desert of ecocide. We are expected to devote ourselves in profitless Karma as Lord Krishna speaks to Arjuna in the Gita.

The path to Karma requires no expectation in return in the worldly domain of human life which both Krishna and his disciple Arjuna know is of transitory nature. As phantoms of the corporeal world, we struggle to get things done. Krishna wants Arjuna to focus on Karma and nothing else because only selfless Karma results in the attainment of salvation from this world. The nature of the world and the nature of human assumptions collide at times to give a sense in the Bhagwat Gita that they require equilibrium to minimize the tension resulting therein.

As Krishna speaks, we get joy of conserving ecology without seeking any practical gain of our action. The Bhagwat Gita, as everyone knows, is teachings of Krishna to Arjuna, a confused warrior in the battle field. Now, in the present crisis of the world, the ecological battle is the worth fighting battle of all other battles. This battle is fought not with weapons but with courage and ethics of our Karma.

Now is the time for every one of us to identify ourselves with Arjuna in the battle field. Our idleness cannot save the ecology and so we should keep ourselves in action being ready for the sacrifice like the prince in aforementioned Buddhist story. We must move from the centre of our 
anthropocentric world view creating fraternity with the entire PAEs of the natural world. The spirit of Karma irrespective of any selfish desire can keep the ecology intact and there lies the true meaning of human life. So, we must remember the dictum of the Gita Karmandya Vadhikaraste.

\section{Works Cited}

Abbey, Edward. "Eco-Defense". Literature and Environment: A Reader on Nature and Culture. Edited by Scott Slovic and John P. O'Grady. Longman, 1995, pp. 344-7.

Arnold, Edwin. The Bhagwat Gita: The Song Celestial. Rajendra Publishing House, 1989.

Bate, Jonathan. "From Red to Green."Green Studies Reader. Edited by Lawrence Coupe. Routledge, 2000, pp.167-71.

Chaudhary, Anuradha. "How Sane are We". Flask Golden Tales. Edited by Moti Nissani and ShreedharLohani. Ekta Books, 2008, pp. 26068.

Coupe, Lawrence. "General Introduction". GreenStudiesReader, pp. 1-7.

Glotfelty, Cheryl. "Literary Studies in an Age of Environmental Crisis".

The Ecocriticism Reader: Landmarks in Literary Ecology. Edited by Cheryl Glotfelty and Harold Fromm, The University of Georgia Press, 1996, pp. xv- xxxviii.

Hotchman, Jhan. "Green Cultural Studies."Green Studies Reader, pp. 18792.

Nissani, Moti. "Too Many People: Too Few Trees." The Heritage of Words. Edited by Shreedhar P. Lohani, Rameswar P. Adhikari and AbhiSubedi. Ekta Books, 1998, pp. 29-36.

Plumwood, Val. "A Man and a Dog in a Life Boat Self-Sacrifice, Animals, and the Limits of the Ethical Theory."Ethics and Environment, vol. 14, no.1, Spring 2009, pp. 129-148.

- - -. "Androcentrism and Anthrocentrism: Parallels and Politics." Ethics and Environment, vol.1, no. 2, Spring 2009, pp. 129-148.

Soper, Kate. "The Idea of Nature."Green Studies Reader. 123.26.

Tondan, R. K. "The Gita: An Introduction". The Bhagwat Gita: TheSongCelestial. 28-50. 